"Mircea cel Batran" Naval Academy Scientific Bulletin, Volume XIX - 2016 - Issue 1

Published by "Mircea cel Batran" Naval Academy Press, Constanta, Romania // The journal is indexed in:

PROQUEST / DOAJ / DRJI / JOURNAL INDEX / I2OR / SCIENCE LIBRARY INDEX / Google Scholar / Crossref /

Academic Keys / ROAD Open Access / OAJI / Academic Resources / Scientific Indexing Services / SCIPIO

\title{
CHARACTERISTICS ANALYSIS, IN DYNAMIC CONDITIONS, FOR THE SHIP POWER OPERATING SYSTEM
}

\author{
Florenţiu DELIU ${ }^{1}$ \\ Vasile DOBREF ${ }^{2}$ \\ Petrică POPOV ${ }^{3}$ \\ Paul BURLACU 4 \\ ${ }^{1}$ Lecturer Ph.D eng.Naval Academy “Mircea cel Batran”, Constanța, florentiu.deliu@anmb.ro \\ 2Professor Ph.D eng. Naval Academy "Mircea cel Batran", Constanța, vasile.dobref@anmb.ro \\ ${ }^{3}$ Lecturer Ph.D Naval Academy “Mircea cel Batran”, Constanța, petrica.popov@anmb.ro \\ ${ }^{4}$ Lecturer Ph.D eng.Naval Academy “Mircea cel Batran”, Constanța, paul.burlacu@anmb.ro
}

Abstract: It was analyzed a naval power system which should ensure the power supply of different consumers. The systematic operations of marine energy systems are based on mathematical models describing the function of specific generators and consumers.

Keywords: electric power system, electric machines, mathematical equation, electric consumers.

\section{Introduction.}

Naval power system consists of synchronous generators driven by diesel engines. Consumers are classified according to electric power and the importance of the various stages of their use. During the operation of vessels may appear different events that should be assessed and controlled so that safety of the ship is not affected. Using mathematical equations of the generator and consumers ship operation was analyzed regarding energy for stable and unstable conditions.

\section{Mathematical equations}

Mathematical model of synchronous generator is characterized by the equations $[1,2.3]$ :

$$
\begin{aligned}
& -\mathrm{U} \sqrt{3} \sin \theta=R_{\mathrm{d}} I_{\mathrm{d}}+L_{\mathrm{d}} \frac{\mathrm{dl}_{\mathrm{d}}}{\mathrm{dt}}-\omega L_{\mathrm{q}} I_{\mathrm{q}}+M_{\mathrm{E}} \frac{\mathrm{dl}_{\mathrm{E}}}{\mathrm{dt}}+M_{\mathrm{D}} \frac{\mathrm{dl}_{\mathrm{D}}}{\mathrm{dt}}-\omega M_{\mathrm{Q}} I_{\mathrm{Q}} \\
& \mathrm{U} \sqrt{3} \cos \theta=\omega L_{\mathrm{d}} I_{\mathrm{d}}+R_{\mathrm{q}} I_{\mathrm{q}}+L_{\mathrm{q}} \frac{\mathrm{dl}_{\mathrm{q}}}{\mathrm{dt}}+\omega M_{\mathrm{E}} I_{\mathrm{E}}+\omega M_{\mathrm{D}} I_{\mathrm{D}}+M_{\mathrm{Q}} \frac{\mathrm{dl}_{\mathrm{Q}}}{\mathrm{dt}} \\
& U_{E}=M_{E} \frac{d l_{d}}{d t}+R_{E} l_{E}+L_{E} \frac{d l_{E}}{d t}+M_{E D} \frac{d l_{D}}{d t} \\
& 0=M_{D} \frac{d l_{d}}{d t}+M_{E D} \frac{d l_{E}}{d t}+R_{D} l_{D}+L_{D} \frac{d l_{D}}{d t} \\
& 0=M_{Q} \frac{d l_{q}}{d t}+R_{Q} l_{Q}+L_{Q} \frac{d l_{Q}}{d t} \\
& J \frac{d \omega}{d t}=p_{1}\left[\left(L_{d}-L_{q}\right) I_{d} l_{q}+M_{E} I_{q} l_{E}-M_{Q}{ }^{\prime} d^{\prime} Q+M_{D} I_{q} I_{D}\right]-M_{\text {motor }}
\end{aligned}
$$

Dynamic stability of the power system is performed by the system of differential equations. Machine parameters are:

$M_{D d}=0.04[\mathrm{H}]$ mutual inductance of the d axis stator;

$M_{Q q}=0051[\mathrm{H}]$ Mutual inductance $q$ axis stator;

$M_{E d}=1[\mathrm{H}]$ mutual inductance excitation;

$M_{E D}=0.53[\mathrm{H}]$ mutual inductance excitation;

$L_{Q}=0.23[\mathrm{H}]$ inductance of $q$ axis;
$L_{D}=0.07[\mathrm{H}]$ inductance of the d-axis stator;

$\mathrm{Lq}=0.06[\mathrm{H}]$ inductance of the $\mathrm{q}$ axis stator;

$L_{D}=0.06[\mathrm{H}]$ inductance of the axis d;

$L_{E}=17.49[\mathrm{H}]$ inductance of the excitation;

$R_{1}=1.4[\mathrm{H}]$ stator resistance;

$R_{E}=39[\Omega]$ resistance of excitation;

$R_{D}=7.86[\Omega]$ resistance of the axis d;

$R_{Q}=29.33[\Omega]$ resistance of involution q axis;

$\Psi_{S N}=0.6 \sqrt{ } 3[\mathrm{~W}$ b] nominal stator flux

We noted:

$I_{d}=\mathrm{X}$-stator current axis d,

$I_{Q}=\mathrm{Z}$-stator current axis q,

$I_{E}=\mathrm{Y}$ current excitation,

$I_{D}=\mathrm{D}$ current of the axis $\mathrm{d}$,

$I_{Q}=\mathrm{Q}$ current of the axis $\mathrm{q}$.

Analyzing 2 cases of operation:

- stable operation to a variable load

- unstable operation at short.

\section{Naval stable operation of the power system}

It is shown below the stable naval operation of the power system using a major consumer of naval vessels (fire pump, ballast pump). The results presented below are three cases providing voltage regulators, frequency, and excitation. 
"Mircea cel Batran" Naval Academy Scientific Bulletin, Volume XIX - 2016 - Issue 1

Published by "Mircea cel Batran" Naval Academy Press, Constanta, Romania // The journal is indexed in: PROQUEST / DOAJ / DRJI / JOURNAL INDEX / I2OR / SCIENCE LIBRARY INDEX / Google Scholar / Crossref / Academic Keys / ROAD Open Access / OAJI / Academic Resources / Scientific Indexing Services / SCIPIO

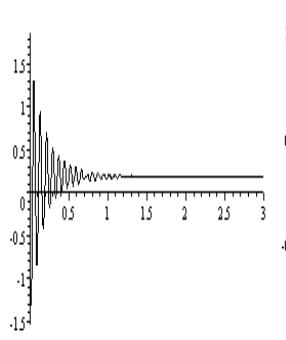

a).

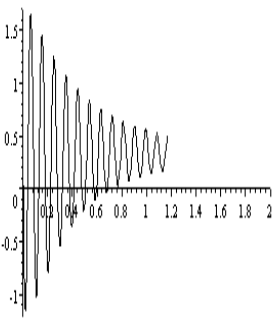

b).

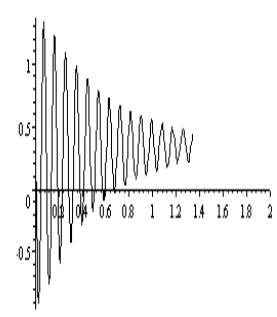

c).

Fig.6. Variation in time of current

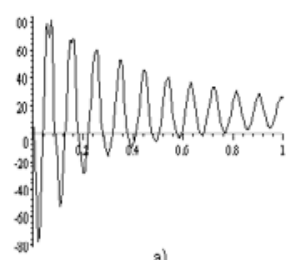

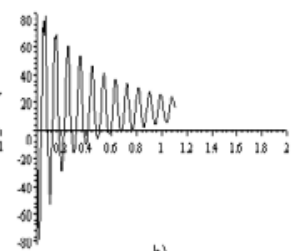

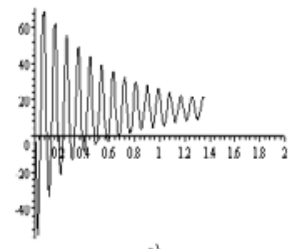

Fig.1. Load angle variation in the three cases

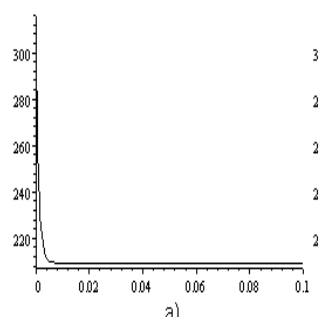

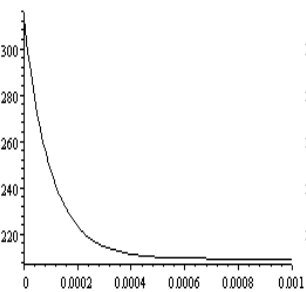

b).

Fig.2. Changes in time of angular stator pulse $w_{1}$

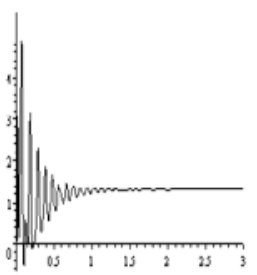

a)

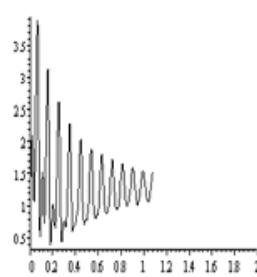

b).

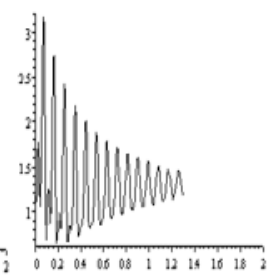

c).

Fig.3. Variation in time of excitation current

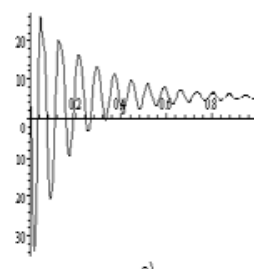

a).

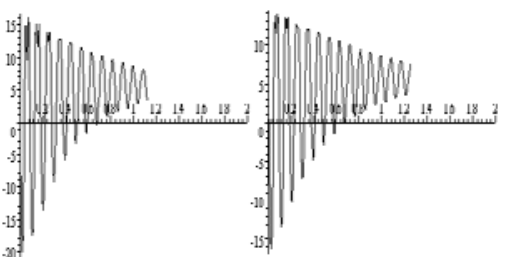

b).

Fig.4. q axis stator current variation

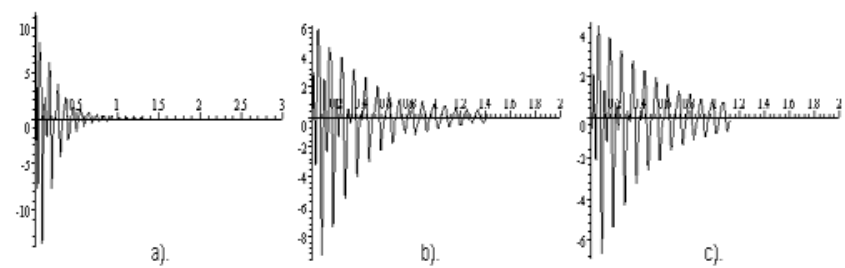

Fig.7. Variation in time of the electromagnetic torque

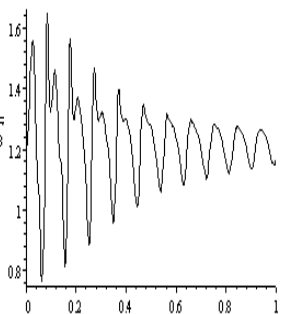

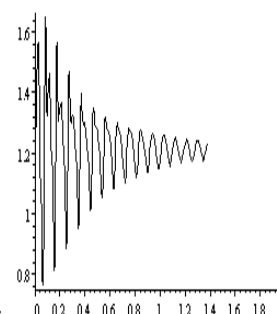

b).

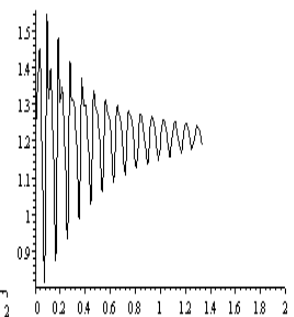

c).

Fig.8. Variation in time of stator flux
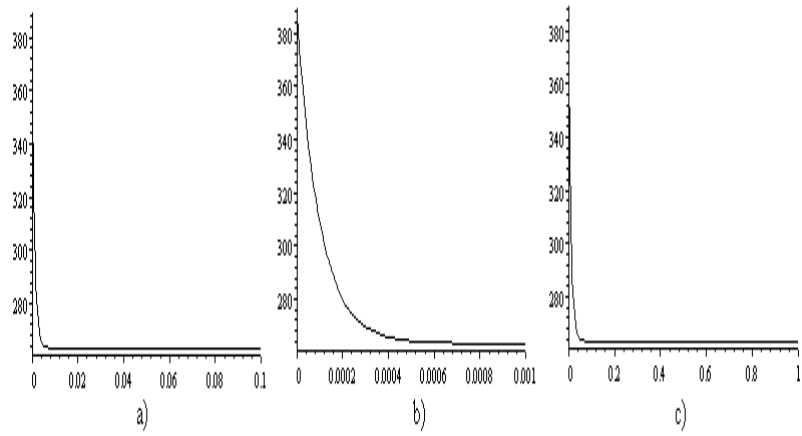

Fig.9.Statoric tension variation over time
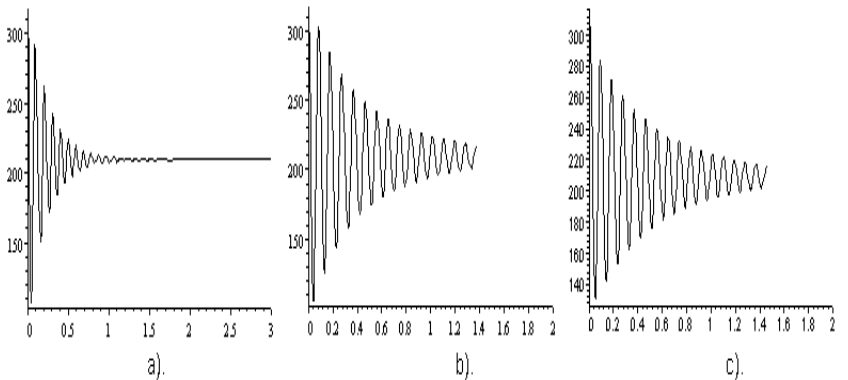
"Mircea cel Batran" Naval Academy Scientific Bulletin, Volume XIX - 2016 - Issue 1

Published by "Mircea cel Batran" Naval Academy Press, Constanta, Romania // The journal is indexed in: PROQUEST / DOAJ / DRJI / JOURNAL INDEX / I2OR / SCIENCE LIBRARY INDEX / Google Scholar / Crossref /

Academic Keys / ROAD Open Access / OAJI / Academic Resources / Scientific Indexing Services / SCIPIO

Fig.10. Changes in time of mechanical angular velocity
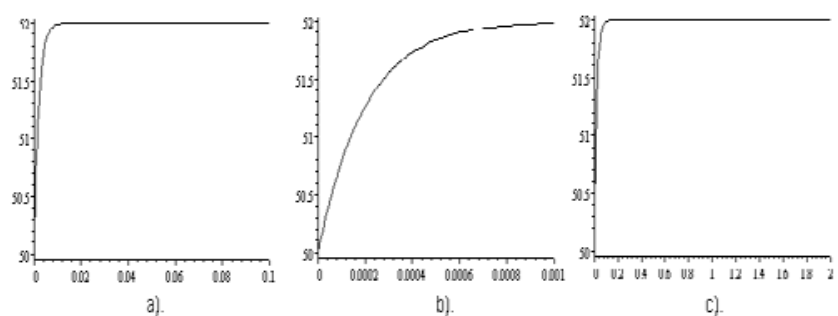

Fig.11. Variation in time of tension $D_{E}$

The results and numerical simulations show that the power system is stable and lead to the following conclusions:

1. For the first charge, load angle is stabilized between 1.5 [s] to 2 [s];

2. The voltage for the stator windings decreases from 380 [V] at 263 [V];

3. angular speed of the rotating magnetic field of the stator has an oscillating and goes to 209.3 $[\mathrm{rad} / \mathrm{s}]$;

4. RMS current excitation is $1.2[\mathrm{~A}]$;

5. the effective value of the stator current oscillates around $25[\mathrm{~A}]$;

6. highs current amortization periods are contained in one [s], 1 [s] 2,5 [s].

7. magnetic flux oscillates around the nominal value;

8. electromagnetic torque changes over time.

\section{Operation unstable of naval power}

In three cases, by simulation, they obtained the following results:

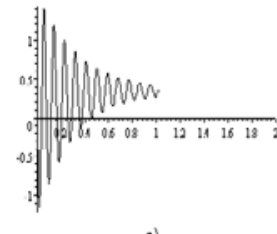

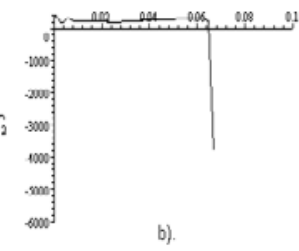

b).

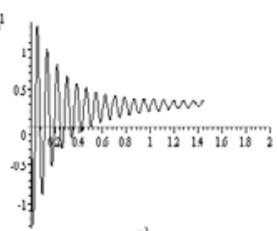

c).
Fig.12. Changes in pregnancy angle $\theta$
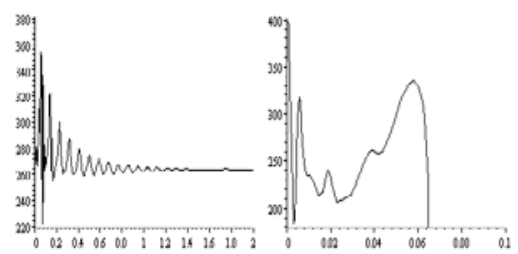

a)

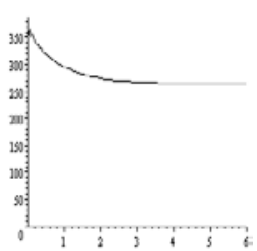

c).

Fig.13. Variation of stator voltage $U$ while

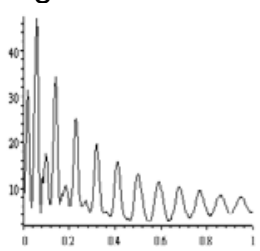

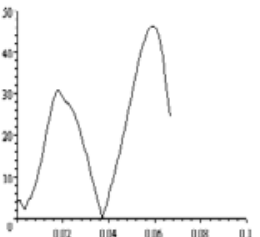

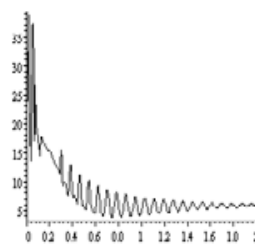

c).

Fig.14. Variation in time of current stator
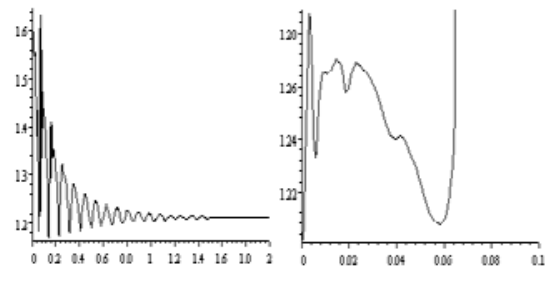

b).

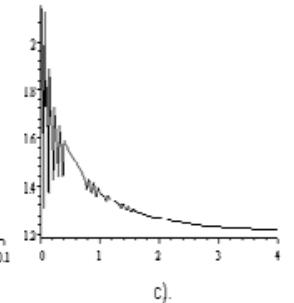

Fig.15. Variation of stator flux in three cases

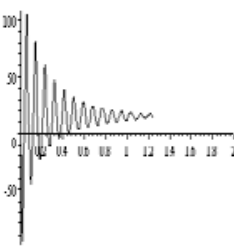

a).

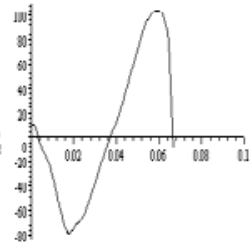

b).

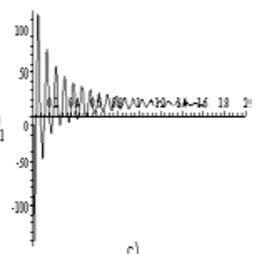

Fig.16. Time variation of the electromagnetic torque

Analyzing further, through numerical simulations, naval power system operation, we found that after about 0063 seconds, it becomes unstable, leading to the following conclusions:

1. the absolute value of the load angle becomes higher than 180 degrees;

2. voltage stator windings becomes null;

3. stator current varies very much;

4. the stator flux than nominal value;

5. magnetic coupling between the stator and rotor is asynchronous.

If the generator is out of synchronization and power system works unstable. 
"Mircea cel Batran" Naval Academy Scientific Bulletin, Volume XIX - 2016 - Issue 1

Published by "Mircea cel Batran" Naval Academy Press, Constanta, Romania /I The journal is indexed in:

PROQUEST / DOAJ / DRJI / JOURNAL INDEX / I2OR / SCIENCE LIBRARY INDEX / Google Scholar / Crossref I

Academic Keys / ROAD Open Access / OAJI / Academic Resources / Scientific Indexing Services / SCIPIO

\section{CONCLUSION}

The paper presents two types of power system dynamic naval operation: stable and unstable operation. In the case of stable operation of the system resulted that it works stable over a finite time interval, after which the generator comes out of synchronization resulting in unstable operation of the system.

In numerical simulations was used the orthogonal model of synchronous generator. Using frequency voltage regulators and leads to stable operation of the system, the most difficult thing is determining the constants of these regulators.

\section{BIBLIOGRAPHY}

[1] Ackermann, Solder L.-An overview of wind energy-status 2002, Renew. Sustain. Energy Rev., vol. 6 , no. ", pp. 67-128, 2002

[2] Kana C. L., Thamodharan M., Wolf A.-System management of a wind energy converter, IEEE Trans. Power Electron., vol. 16, no. 3, pp. 375-381, May 2001.

[3] Quaschning V.- Understanding Renewable Energy Systems, ISBN 1-84407-128-6, London Carl Hanser Verlag GmbH \& Co KG, 2005.

[4] Ullah N.R., K.Bhattacharya, and T.Thiringer, "Wind Farms as Reactive Power Ancillary Service ProvidersTechnical and Economic Issues ", IEEE Trans. Energy Convers., vol. 24, no. 3, pp.661-672, September 2009.

[5]Deliu F., Transitory phenomenon into naval electrical equipment hybrid powered, Ph.D. Thesis, POLITEHNICA Timişoara, 2011

[6].Jiao S., Hunter G., Ramsden V., Patterson D., Control system design for a $20 \mathrm{KW}$ wind turbine generator with a boost converter and bank. battery load, in Proc. IEEE PESC, Vancouver, BC, Canada, Jun. 2001, pp. 2203-2206

[7]. Lane N., Boesch D. F., Vision 2033, part 6: Energy, the environment, and global change. The American Association for the Advancement of Science [Online].2004 